\title{
Performance and Evaluation of Six Row Self- propelled Paddy Transplanter under Different Puddling Methods
}

\author{
M. Murali ${ }^{*}$, M. Anantachar' ${ }^{1}$ K. V. Prakash', Sunil Shirwal' ${ }^{1}$ and U. Satishkumar ${ }^{2}$ \\ ${ }^{1}$ Farm Machinery and Power Engineering Department, CAE, University of Agricultural Sciences, \\ Raichur - 584104, Karnataka, India; \\ murruaek919@gmail.com \\ ${ }^{2}$ Soil and Water Engineering Department, CAE, University of Agricultural Sciences, Raichur - 584104, \\ Karnataka, India
}

\begin{abstract}
Self-propelled rice transplanter was evaluated under different puddling has been conducted Agricultural Research Station, Gangavati during 2014-15. KUBOTA Model NSPU-68C (6 rows) transplanter was used in an experiment. This transplanter (Kubato Model) was in view to decrease the cost operation and it is used for transplanting purpose. The number of floating hills increased with an increasing level of puddling. The numbers of buried hills were reduced significantly with an increase in the sedimentation period as well as the both No. of passes. The field efficiency, field capacity, and fuel consumption of the transplanter were, $62.96 \%, 0.54 \mathrm{ha} / \mathrm{h}$ and $4.29 \mathrm{l} / \mathrm{h}$, respectively. The cost of operation of tractor operated disc puddler, rotovator and rotomixuer was $484 \mathrm{Rs} / \mathrm{h}, 538 \mathrm{Rs} / \mathrm{h}, 551 \mathrm{Rs} / \mathrm{h}$ and cost of operation of transplanter is $965 \mathrm{Rs} / \mathrm{h}$. Compared to manual transplanting of paddy the machine was found to be farmer friendly and feasible in terms of time, money and labour requirement.
\end{abstract}

Keywords: Floating Hills, Fuel Consumption, Missing Hills, Paddy Transplanter

\section{Introduction}

Paddy (Oryza sativa) is one of the most essential produce and staple food for millions of people which is grown in many countries across the world. The total area of paddy cultivation in India is 42.40 million ha, which is the largest in the world as beside the total area of 148.30 million ha. West Bengal has the highest paddy production, while Punjab has the highest productivity of paddy among the different paddy growing states of India ${ }^{3}$.
The total area under paddy in Karnataka is 1.54 million ha with an annual production of 3.9 million tonnes and with a productivity of $2974 \mathrm{~kg} / \mathrm{ha}{ }^{4}$.Transplanting is healthy and vigorous practice of produces uniform seedling stand with higher yield than traditional method.

Customarily with the help of manual transplanting paddy is mostly grown. Manual transplanting requires a large number of labours besides concerning drudgery and is also very expensive. Lack of labours availability is another major problem in most paddy growing region of

${ }^{*}$ Author for correspondence 
the country. Manual transplanting takes about 250-350 $\mathrm{man} \mathrm{h} / \mathrm{ha}$ which is about $25 \%$ of the total labour requirement of the yield 5 . Hence, there is a need of less expensive, farmer friendly and labour saving method of paddy transplanting. The mechanical transplanting of paddy have been considered the most promising alternative, as it saves labour, ensure timely transplanting and attain optimum plant density that contribute to high productivity. To overcome above mention problems, the study was conducted on self-propelled six row paddy transplanter.

\section{Materials and Methods}

A transplanter KUBOTA Model NSPU-68C (6 rows), was used in an experiment. It is a six-row rice trans- planter suitable for mat type seedlings. The transplanter is operated in double acting mechanism. The transplanter consists of $17 \mathrm{hp}$ air cool petrol engine powered with six spare seedling racks for filling of trays intermittently and it is provided with power steering. The adjustments involved in machine are number of seedlings per hill, depth of transplanting and hill-to-hill distance. During transplanting depth of transplanting was maintained from 2 to $5 \mathrm{~cm}$. The row-to-row spacing is $30 \mathrm{~cm}$, hill-to-hill distance $12 \mathrm{~cm}$ was fixed depending on desired plant population and operating speed 0-1.62 $\mathrm{m} / \mathrm{s}$ was maintained. Specifications of self-propelled paddy transplanter are presented in Table 1.

The experiments were conducted during kharif, 2014-15 at Agricultural Research Station, Gangavati.

Table 1. Specifications of Kubota transplanter KUBOTA Model NSPU-68C (6 rows)

\begin{tabular}{|c|c|c|}
\hline Sl. no. & Parameters & Descriptions \\
\hline 1 & Model & NSPU-68C \\
\hline 2 & Type & Ride on type 4 Wheel \\
\hline 3 & Overall dimensions, mm & $3000 \times 2210 \times 2570$ \\
\hline 4 & Minimum ground clearance, $\mathrm{mm}$ & 430 \\
\hline 5 & Weight, kg & 590 \\
\hline 6 & Engine Model & GZ460-P-CHN \\
\hline 7 & Type & $\begin{array}{c}4 \text { - cycle, water - cooled } \mathrm{OHC} \\
\text { Gasoline }\end{array}$ \\
\hline 8 & Power & $17 \mathrm{Hp}$ \\
\hline 9 & Applicable Fuel & Un leaded gasoline for automobile \\
\hline 10 & Fuel tank capacity, 1 & 17 \\
\hline 11 & Starting method & Electric \\
\hline 12 & Battery & $12 \mathrm{~V}$ \\
\hline 13 & Fuel Consumption, $1 / \mathrm{h}$ & $4-5$ \\
\hline 14 & Shifting system & Hydro static transmission ( HST) \\
\hline 15 & Steering & Power steering \\
\hline 16 & Transplanting mechanism & Rotary, Forced Planting \\
\hline 17 & Number of rows & 6 rows type \\
\hline 18 & Row to row spacing, $\mathrm{cm}$ & 30 \\
\hline 19 & Hill space, $\mathrm{cm}$ & $12,14,16,18,21$ \\
\hline 20 & Planting Depth, $\mathrm{cm}$ & $2-5$ \\
\hline 21 & Number of hills per, $\mathrm{m}^{2}$ & $90,80,70,60,50$ \\
\hline 22 & Seedlings height, $\mathrm{cm}$ & 8 to 25 \\
\hline 23 & Number of leaves & $2-4.5$ \\
\hline 24 & Operation speed, $\mathrm{m} / \mathrm{s}$ & $0-1.62$ \\
\hline
\end{tabular}


The selected variety of paddy for this study was BPT. The depth of water at the time of puddling was $10 \mathrm{~cm}$. The mat density was measured from five randomly selected plants in mat density per $\mathrm{cm}^{2}$.the average mat density was observed to be 2.36 to $2.52 \mathrm{~cm}$ at time of planting. The maximum seedling height at the time of planting is 22.60 $\mathrm{cm}$ and $23.57 \mathrm{~cm}$ seedling height and minimum is at the base of seeding.

\subsection{Field Preparation and Transplanting}

The tractor drawn cultivator was used preparing the land for levelling in case of farmers practice. Second type of land preparation was puddling with rotovator followed by levelling using tractor drawn spike tooth harrow. The other one was puddling with rotomixure and levelling was done by using spike tooth harrow. Transplanting was done at different sedimentation period by the self-propelled transplanter.

\subsection{Puddling Equipment}

The puddling equipment are tractor drawn Cultivator disc puddler + spiketooth harrow (Balla) and Puddling with rotovator + spiketooth harrow (Balla) and puddling with rotomixure + spiketooth harrow (Balla) were used for puddling the experiment field. During the field tests the field parameters were recorded. The parameters relevant to machine performance determination and soil protection are measured. Procedure followed for calculation is discussed under the following section.

\subsection{Missing Hills}

It is the ratio of the total number of hills without seedlings to the total number of hills expressed in percentage and it can be calculated by the following equation ${ }^{8}$.

$$
\mathrm{H}_{\mathrm{pm}}=\frac{\mathrm{H}_{\mathrm{m}}}{\mathrm{H}_{\mathrm{t}}} \times 100
$$

where,

$\mathrm{H}_{\mathrm{pm}}=$ Percent missing hills, per cent

$\mathrm{H}_{\mathrm{m}}=$ Total number of missing hills in the sampling area

$\mathrm{H}_{\mathrm{t}}=$ Total number of hills in the sampling area

\subsection{Floating Hills}

It is the ratio of the total number of hills floating after transplanting to the total number of hills expressed in percentage and it can be calculated by the following equation ${ }^{5}$.

$$
\text { Floating Hills }(\%)=\frac{\mathrm{FH}}{\mathrm{TNH}} \times 100
$$

where,

$\mathrm{FH}=$ Percent floating hills, per cent

$\mathrm{FH}=$ number of floating hills, $\mathrm{m}^{-2}$

$\mathrm{TNH}=$ Total number of hills in sampling area, $\mathrm{m}^{-2}$

\subsection{Buried Hills}

It is the ratio of the number of buried hills after transplanting to the total number of hills expressed in percentag ${ }^{5}$. Buried hill were calculated by the following formulae'.

$$
\begin{aligned}
& \text { Buried Hills }(\%)=\frac{\mathrm{BH}}{\mathrm{TNH}} \times 100 \\
& \text { where, } \\
& \mathrm{BH}=\text { Percent buried hills, per cent } \\
& \mathrm{BH}=\text { number of buried hills, } \mathrm{m}^{-2} \\
& \mathrm{TNH}=\text { Total number of hills transplanted, } \mathrm{m}^{-2}
\end{aligned}
$$

\section{Results and Discussion}

It was observed from the results (Table 2) that puddling method has influenced on floating hills. Floating hills are different for different methods. The Floating hills increased significantly when level of puddling increased from one to two passes in all treatment and the Floating hills is decreased with increased sedimentation periods. It was also noticed that Floating hills was more in case of disc puddler as compared to that other treatment. It was reported that the floating hills increased with an increasing level of puddling in the experiment. Similar readings are reported by ${ }^{9}$. It was noticed that sedimentation period is increase the floating hill decreased for all treatments ${ }^{10}$.

\subsection{Missing hills}

The missing hills is depends on machine performance. The missing hills increased significantly when level of puddling increased from one to two passes in all treatment and the missing hills is decreased with increased sedimentation periods. It was also noticed that missing hills was more in case of disc puddler as compared to that other treatments. It was observed from the Table 3. 
Table 2. Effect of puddling method, sedimentation period, and number of passes on, floating hills

\begin{tabular}{|c|c|c|c|c|}
\hline \multirow[t]{3}{*}{ Sl. no. } & \multirow[t]{3}{*}{ Puddling Methods, T } & \multirow{3}{*}{$\begin{array}{c}\text { Sedimentation } \\
\text { Period, h }\end{array}$} & \multicolumn{2}{|c|}{ Floating hills, percentage } \\
\hline & & & \multicolumn{2}{|c|}{ No. of passes } \\
\hline & & & $\mathrm{N}_{1}$ & $\mathrm{~N}_{2}$ \\
\hline \multirow[t]{3}{*}{1} & \multirow[t]{3}{*}{ Disc puddler } & $\mathrm{S}_{1}$ & 4.48 & 5.28 \\
\hline & & $\mathrm{S}_{2}$ & 3.06 & 3.36 \\
\hline & & $\mathrm{S}_{3}$ & 1.92 & 1.96 \\
\hline \multirow[t]{3}{*}{2} & \multirow[t]{3}{*}{ Rotovator } & $\mathrm{S}_{1}$ & 4.15 & 4.66 \\
\hline & & $\mathrm{S}_{2}$ & 2.58 & 3.21 \\
\hline & & $\mathrm{S}_{3}$ & 1.50 & 1.65 \\
\hline \multirow[t]{3}{*}{3} & \multirow[t]{3}{*}{ Rotomixure } & $\mathrm{S}_{1}$ & 3.89 & 5.10 \\
\hline & & $\mathrm{S}_{2}$ & 2.15 & 3.06 \\
\hline & & $\mathrm{S}_{3}$ & 1.53 & 1.92 \\
\hline
\end{tabular}

\subsection{Buried Hills}

Effect of puddling methods (T), sedimentation period, (S) and No. of passes N1 and N2 on buried hills is presented in Table 4 . The buried hills increased significantly when level of puddling increased from one to two passes in all treatment and the buried hills is decreased with increased sedimentation periods. It was also noticed that buried hills was more in case of disc puddler as compared to that other treatment. It was reported that the buried hills increased with an increasing level of puddling in the experiment9, it was noticed that sedimentation period is increase the buried hills decreased for all treatments7.

It was observed from the result is that the fuel consumption $1.43 \mathrm{l} / \mathrm{h}$. and field capacity $0.42 \mathrm{ha} / \mathrm{h}$, field efficiency 61.68 per cent. Cost of operation of self-propelled transplanter is calculated based on fixed cost and variable cost. It was observed that, cost of operation of tractor operated rotomixure was Rs.551/h. Breakeven point and payback period were $113.8 \mathrm{~h} /$ annum and 2.06 years, cost of operation of tractor operated rotovator was Rs.538/h. Breakeven point and payback period were

Table 3. Effect of puddling method, sedimentation period, and number of passes on, missing hills

\begin{tabular}{|c|c|c|c|c|}
\hline \multirow[t]{3}{*}{ Sl. No. } & \multirow[t]{3}{*}{ Puddling Methods, T } & \multirow{3}{*}{$\begin{array}{l}\text { Sedimentation } \\
\text { Period, } \mathrm{h}\end{array}$} & \multicolumn{2}{|c|}{ Missing Hills, Percentage } \\
\hline & & & \multicolumn{2}{|c|}{ No. of passes } \\
\hline & & & $\mathrm{N}_{1}$ & $\mathrm{~N}_{2}$ \\
\hline \multirow[t]{3}{*}{1} & \multirow[t]{3}{*}{ Disc puddler } & $S_{1}$ & 5.27 & 6.50 \\
\hline & & $\mathrm{S}_{2}$ & 4.36 & 5.82 \\
\hline & & $\mathrm{S}_{3}$ & 2.60 & 3.57 \\
\hline \multirow[t]{3}{*}{2} & \multirow[t]{3}{*}{ Rotovator } & $\mathrm{S}_{1}$ & 4.32 & 5.71 \\
\hline & & $\mathrm{S}_{2}$ & 3.17 & 4.60 \\
\hline & & $\mathrm{S}_{3}$ & 2.28 & 3.58 \\
\hline \multirow[t]{3}{*}{3} & \multirow[t]{3}{*}{ Rotomixure } & $\mathrm{S}_{1}$ & 4.31 & 6.14 \\
\hline & & $\mathrm{S}_{2}$ & 3.70 & 5.64 \\
\hline & & $\mathrm{S}_{3}$ & 2.06 & 2.91 \\
\hline
\end{tabular}


Table 4. Effect of puddling method, sedimentation period, and number of passes on buried hills

\begin{tabular}{|c|c|c|c|c|}
\hline \multirow[t]{3}{*}{ Sl. No. } & \multirow[t]{3}{*}{ Puddling Methods, T } & \multirow{3}{*}{$\begin{array}{l}\text { Sedimentation } \\
\text { Period, } \mathrm{h}\end{array}$} & \multicolumn{2}{|c|}{ Buried hills, percentage } \\
\hline & & & \multicolumn{2}{|c|}{ No. of passes } \\
\hline & & & $\mathrm{N}_{1}$ & $\mathrm{~N}_{2}$ \\
\hline \multirow[t]{3}{*}{1} & \multirow[t]{3}{*}{ Disc puddler } & $\mathrm{S}_{1}$ & 4.87 & 5.94 \\
\hline & & $\mathrm{S}_{2}$ & 2.85 & 3.86 \\
\hline & & $\mathrm{S}_{3}$ & 1.32 & 1.96 \\
\hline \multirow[t]{3}{*}{2} & \multirow[t]{3}{*}{ Rotovator } & $\mathrm{S}_{1}$ & 3.86 & 4.93 \\
\hline & & $\mathrm{S}_{2}$ & 1.90 & 3.03 \\
\hline & & $\mathrm{S}_{3}$ & 0.75 & 1.56 \\
\hline \multirow[t]{3}{*}{3} & \multirow[t]{3}{*}{ Rotomixure } & $\mathrm{S}_{1}$ & 3.33 & 4.87 \\
\hline & & $\mathrm{S}_{2}$ & 1.97 & 2.85 \\
\hline & & $\mathrm{S}_{3}$ & 0.86 & 0.95 \\
\hline
\end{tabular}

$96.44 \mathrm{~h} /$ annum and 1.87 years, cost of operation of tractor operated disc puddler was Rs.484/h. Breakeven point and payback period were $54.26 \mathrm{~h} /$ annum and 0.97 years. The transplanter was Rs.965/h. Breakeven point and payback period were $418 \mathrm{~h} /$ annum and 7.4 years.

\section{Conclusion}

Following conclusions are drawn from the study

- The number of floating hills increased with an increasing level of puddling.

- The number of buried hills increased with an increasing level of puddling from one to two passes.

- The numbers of buried hills were reduced significantly with an increase in the sedimentation period as well as the both No. of passes.

- The cost of operation of tractor operated disc puddler, rotovator and rotomixer was $484 \mathrm{Rs} / \mathrm{h}, 538 \mathrm{Rs} / \mathrm{h}, 551$ $\mathrm{Rs} / \mathrm{h}$ and cost of operation of transplanter is $965 \mathrm{Rs} / \mathrm{h}$.

\section{References}

1. The Hindu Survey of Indian Agriculture; 2009. p. 23-6.

2. Ministry of Agriculture, Govt. of India [Internet]. 2013. Available from: http:// www.indiastat.com.

3. Ministry of Agriculture, Govt. of India [Internet]. 2012. Available from: http:// www.indiastat.com.
4. The Hindu Survey of Indian Agriculture; 2010. p. 43-46.

5. Behera BK, Varshney, BP, Goel AK. Effect of puddling on puddled soil characteristics and performance of self-propelled transplanter in rice crop. International Journal of Agricultural and Biological Engineering. 2009; 10(5):1-18.

6. Rao MV, Pradhan SV. Cultivation practice. Rice Production Manual, International Committee for Animal Recording; 1973. p. 71-95.

7. Behera BK, Varshney BP. Studies on optimization of puddled soil characteristics for self-propelled rice transplanter. Agricultural Mechanization in Asia. 2003; 34(3):12-16.

8. Muhammad AM. Performance evaluation of kukje self propelled rice transplanter. Agricultural Engineers Today. 2013; 29(4): 11-17.

9. Chaudhary VP, Varshney BP. Influence of seedling mat characteristics and machine parameters on performance of self propelled rice transplanter. Agricultural Mechanization in Asia. 2003; 34(2):13-18.

10. Behera BK, Varshney BP, Swain S. Influence of seedling mat characteristics on the performance of self propelled rice transplanter. Agricultural Engineers Today. 2007; 31(1):1-6.

11. Chaudhary VP, Varshney BP. Performance evaluation of self-propelled rice transplanter under different puddled field conditions and sedimentation periods. Agricultural Mechanization in Asia. 2003; 34(2):23-33. 